\title{
Assessment of tolerability and acceptability of alcohol- based solution according to World Health Organization (WHO) Protocol among Employees and Students of Kalinga State University (KSU)
}

\author{
Bernadette C. Aggabao, PhD; Melanie Santos-Manuel, MST
}

Received: 16 Nov 2021; Received in revised form: 19 Dec 2021; Accepted: 25 Dec 2021; Available online: 31 Dec 2021 (C2021 The Author(s). Published by Infogain Publication. This is an open access article under the CC BY license (https://creativecommons.org/licenses/by/4.0/).

\begin{abstract}
The present pandemic threatens not only the people's health but the demand of ABHR (Alcohol Based Hand-rub) which can lead to improved compliance of hand hygiene practices. This study was designed to determine the acceptability and tolerability of ABHR for the hand hygiene of employees and students of Kalinga State University. 40 participants were enumerated according to the WHO protocol which comprised primarily of faculty and staff (60\%), the majority were female (58\%). Few of the respondents reported asthmatic conditions (10\%) and any non-work activity/ies (7.5\%) that would damage their skin in the duration of the test period. The majority of the criteria set by the WHO for the acceptability of the product were deemed acceptable except for the two parameters, texture (45\%) and drying effect (50\%) which is below the recommended percentage of the WHO. The said parameters were suggested to be improved for the next study. The respondents reported their satisfaction with the produced ABHR and added that the test product improved their hand hygiene practices (75\%). A separate study should be considered to assess the Product tolerability and skin compatibility with a trained medical staff per WHO Protocol so that objective assessment by an independent observer as well as subjective assessment will be assessed.
\end{abstract}

Keywords-Alcohol-based solution, product tolerability, Hand-hygiene practices.

\section{INTRODUCTION}

Background of the study

The unexpected coming of COVID-19 gave an instant problem nationwide that leads to the cramming of people to have a panic buying to the supermarkets to their necessity needs especially for the disinfectants that believe to kill right away the virus. Because of this panic buying, it cannot denied that there was scarcity of supplyto sanitizers. Some businesses even hoard their products and some gave overprice to their products. Though body soaps are still available for hand hygiene, they still play a central role in the prevention of infections. Some have the irked in using them because they are not as handy as the rubbing alcohol or other hand sanitizers. However, in healthcare and cosmetology, hand hygiene is insufficient, which is associated with increased morbidity, mortality, and healthcare costs.

Because of this scenario, the initiatives of everyone was enjoined. Many of them resorted in making or manufacturing their own hand sanitizers and gels, believing that these could help kill and disinfect virus and bacteria. It is well known, however, that sanitizers can be done at home as readily made available or what we call as the Do it by Yourself a.k.a DIY. However, not all sanitizers and gels are tolerated by users. Some of the users have allergies that could lead not to use these sanitizers. Hence, this research was conceptualized to assess the tolerability and acceptability of the users of alcohol based solution among the employees and students of Kalinga State University, of which in accordance to the protocol of the World Health Organization (WHO). 


\section{A. Conceptual Framework}

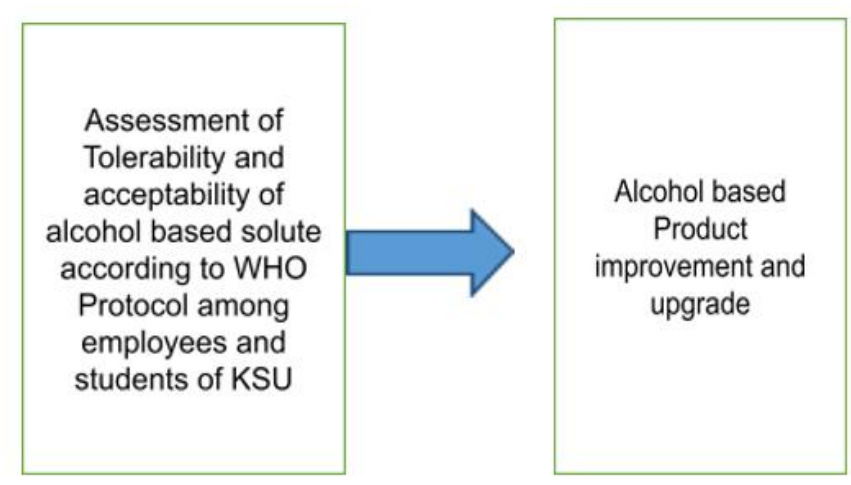

\section{B. Objectives of the Study}

The study aims to evaluate the acceptability and tolerability of alcohol based antiseptic solution among KSU: Employees and students using WHO Protocol. Specifically, it aims to

1. Assessed the hygiene practices of the selected respondents

2. acceptability and tolerability of alcohol based antiseptic solution in terms of:
a. color
b. smell
c. texture
d. irritation
e. drying effect
f. ease of use
g. speed of drying
h. application and
i. overall evaluation

3. Assessed the skin after use of the test product

\section{Scope and delimitation of the study}

Test product to be used the study will be produced at the Central Science Laboratory of the Kalinga State University from the period of June 2020-July 2020. The said project which is funded by CHED is a joint project of KSU and Department of Science and Technology (DOST). The project aims to produce alcohol based solution from raw materials available amidst COVID-19 pandemic which includes sugar and bread yeast. The process relies on fermentation in ethanol conversion of sugar by the yeast and will be distilled to attain higher alcohol percentage. The antiseptic solution will be utilized by the employees and students of this institution from the period of April 2020 up to present.
The study will include 30 employees and 10 students to meet the 40 participants mentioned in WHO Protocol for Assessment of Tolerability and Acceptability of an alcohol based hand rub in use. Testing period will be measured and considered from June-July 2020. The assessment and data validation will be from August to December 2020.

Self-administered questionnaire will be given to the respondents who received the product last June-July 2020. Questionnaire 1will include the demographic information of the participant and its evaluation of skin tolerance and frequency of hand hygiene practices a month after the use of the product.

Self-Assessment through self-administered questionnaire will also be given to answer Questionnaire 2 which will evaluate the test product, skin condition and frequency of hand hygiene practices 3-5 days after use and a month of product use.

The following will be the respondents identified based on acknowledgement receipt documented by the Central Science Laboratory:

\begin{tabular}{|c|l|}
\hline COLLEGE/OFFICE/UNIT & $\begin{array}{l}\text { NO. OF } \\
\text { RESPONDENTS }\end{array}$ \\
\hline CEIT & 3 \\
\hline CCJE & 3 \\
\hline CA & 2 \\
\hline CHNS & 2 \\
\hline CLA & 2 \\
\hline COED & 2 \\
\hline LHS & 3 \\
\hline ADMINISTRATION & 10 \\
$-\quad$ GSO & \\
$-\quad$ Registrar & \\
$-\quad$ Finance Office & \\
$-\quad$ Guard House & \\
\hline STUPply & 10 \\
\hline
\end{tabular}

\section{REVIEW OF RELATED LITERATURE}

The result of the study of Donoghue, Margaret, et.al. (2019) revealed that the elderly residents preferred both of the test products to the usual one used by the home, which was a liquid rinse formulation containing glycerol as humectant. It was also found out that subjects in their study found the portable bottles of gel with plastic caps difficult 
to manipulate. This may explain why the product was rated lower overall than the foam with some elderly misplacing their bottles of gel during the test period. The authors further disclosed that Product tolerability and skin compatibility are also critical, and studies have demonstrated that a product that is not well tolerated will not be well-accepted.

In the study by Wolfensberger, Aline, et. al., they concluded that the new ABHR (EVO9; Ecolab) was well tolerated and user-accepted with a potential for improvement regarding texture, i.e. stickiness. They added that while the subjective usability and tolerability rating by the users should be interpreted with caution, the skin tolerability assessed by a trained observer may be more reliable. The WHO protocol proofed to be useful but demanding for everyday application.

\section{METHODOLOGY}

\section{Locale of the Study}

All information needed to answer the objectives will be conducted solely at Kalinga State University for the period of April 2020 to December 2020. Faculty and students will be asked to answer the prepared questionnaire during their vacant time.

\section{Research Design}

This is a survey-based study where a selfadministered questionnaire through self- assessment will be adapted and modified from the study of WHO Protocol for Evaluation of Tolerability and Acceptability of Alcoholbased Hand Rub in Use.

Questionnaire 1 would include the demographic information of the participant and its evaluation of skin tolerance and frequency of hand hygiene practices a month after the use of the product.

Self-Assessment through self-administered questionnaire will be also given to answer Questionnaire 2 which evaluate the test product, skin condition and frequency of hand hygiene practices 3-5 days after use and a month of product use.

Descriptive statistics like mean median and standard deviation will be used to analyze the data gathered.

\section{Respondents of the Study}

The survey population included 40 participants based on the recommendation of WHO Protocol for Evaluation of Tolerability and Acceptability of Alcoholbased Hand rub in Use. Three (3) respondents were selected from the College of Engineering and Information technology (CEIT); two (2) from the
College of Forestry (CF); three (3) from the College of Criminal Justice Education (CCJE); two(2) from the College of Health and Natural Sciences (CNHS); two(2) from the College of Agriculture (CA); two (2) from the College of Liberal Arts; two (2) from the College of Education (CoEd); three (3) from the Laboratory High School (LHS); ten (10) from the administration and ten (10) students will be selected as well.

\section{Instrumentation}

A self-administered questionnaire adapted and modified from the WHO Protocol for Evaluation of Tolerability and Acceptability of Alcohol-based Hand rub in Use will be used in the study.

\section{Data Gathering Procedure}

The modified and adapted questionnaire for gathering will beused after due consultation with the Office of the Central Laboratory and Office of the Director of Research and may be adjusted.

\section{Data Analysis}

Data collected will be analysed using descriptive statistics, which included the calculation of measures of central tendency (means and medians), standard deviations and frequency counts; these were displayed using frequency tables and bar charts. To analyze the responses to questionnaire, a score will be assigned on each responses that can be calculated which included the following variables:

\section{REFERENCES}

[1] Berardi, A., Perinelli, D. R., Merchant, H. A., Bisharat, L., Basheti, I. A., Bonacucina, G., Cespi, M., \& Palmieri, G. F. (2020). Hand sanitisers amid CoViD-19: A critical review of alcohol-based products on the market and formulation approaches to respond to increasing demand. International journal of pharmaceutics, 584, 119431. https://doi.org/10.1016/j.ijpharm.2020.119431

[2] Donoghue, Margaret Q., et.al. Acceptability and tolerability of alcohol-based hand hygiene products for elderly residents in long- term care: A crossover study, 2019. Research/Open Access.

[3] Wolfensberger, Aline, et.al. Evaluating the tolerability and acceptability of an alcohol-based hand rub real-life experience with the WHO protocol. Journal List.

[4] Antimicrobial Resist Control. V.4, 2015; 4:18.

[5] Todd E.C.D., Michaels B.S., Holah J., Smith D., Greig J.D., Bartleson C.A. Outbreaks Where Food Workers Have Been Implicated in the Spread of Foodborne Disease. Part

[6] 10. Alcohol-Based Antiseptics for Hand Disinfection and a Comparison of Their Effectiveness with Soaps. J. Food Prot. 2010; 73:2128-2140. doi: 10.4315/0362-028X73.11 .2128 
[7] Suchomel M., Rotter M. Ethanol in pre-surgical hand rubs: concentration and duration of application for achieving European Norm EN 12791. J. Hosp. Infect. 2011;77:263266. doi: 10.1016/j.jhin.2010.10.014.

[8] KampfG. Efficacy of ethanol against viruses in handdisinfection. J.Hosp. Infect. 2018;98:331-338. doi: 10.1016/j.jhin.2017.08.025.

[9] Cartner T., Brand N., Tian K., Saud A., Carr T., Stapleton P., Lane M.E., Rawlings A.V. Effect of different alcohols on stratum corneum kallikrein 5 and phospholipase A2 together with epidermal keratinocytes and skin irritation. Int. J. Cosmet. Sci. 2017;39:188-196. doi: 10.1111/ics.12364

[10] Tarka P., Gutkowska K., Nitsch-Osuch A. Assessment of tolerability and acceptability of an alcohol-based hand rub according to a WHO protocol and using apparatus tests. Antimicrob. Resist. Infect. Control. 2019;8:191. doi: 10.1186/s13756-019-0646-8.

[11] Boyce J., Chartier Y., Chraiti M., Cookson B., Damani N., Dharan S. Geneva World Heal. Organ; 2009. WHO guidelines on hand hygiene in health care.

[12] FDA, U.S., 2020. Temporary Policy for Preparation of Certain Alcohol-Based Hand Sanitizer Products During the Public Health Emergency (COVID-19) Guidance for Industry.

[13] Edmonds S.L., Macinga D.R., Mays-Suko P., Duley C., Rutter J., Jarvis W.R., Arbogast J.W. Comparative efficacy of commercially available alcohol-based hand rubs and World Health Organization-recommended hand rubs: Formulation matters. Am. J. Infect. Control. 2012;40:521525. doi: 10.1016/j.ajic.2011.08.016.

[14] Eggerstedt S. Comparative efficacy of commercially available alcohol-based hand rubs and World Health Organization-recommended hand rubs. Am. J. Infect. Control. 2013;41:472-474

[15] Wilkinson M.A.C., Ormandy K., Bradley C.R., Fraise A.P., Hines J. Dose considerations for alcohol-based hand rubs. J. Hosp. Infect. 2017;95:175-182. doi:10.1016/j.jhin.2016.12.023.

[16] Grayson ML, Russo PL, Cruickshank M, Bear JL, Gee CA, Hughes CF, et al. Outcomes from the first 2 years of the Australian National Hand Hygiene Initiative. Med J Aust [Internet]. 2011 [cited 2020 September 29];195:615-9.
Available

from:

http://www.ncbi.nlm.nih.gov/pubmed/22107015.

[17] Pittet D, Allegranzi B, Sax H, Chraiti M-N, Griffiths W, Richet H, et al. Double-Blind, Randomized, Crossover Trial of 3 Hand Rub Formulations: Fast-Track Evaluation of Tolerability and Acceptability. Infect Control Hosp Epidemiol [Internet]. 2007 [cited 2020 September 29];28:1344-51. Available from: http://www.ncbi.nlm.nih.gov/pubmed/17994514.

[18] Ho M, Seto W, Wong L, Wong T. Effectiveness of Multifaceted Hand Hygiene Interventions in Long-Term Care Facilities in Hong Kong: A Cluster-Randomized Controlled Trial. Infect Control Hosp Epidemiol [Internet]. 2012 [cited 2020 September 29]; 33:761-7. Available from: https://www.cambridge.org/core/product/identifier/S019594 1700031234/type/journal_arti cle

[19] Yeung WK, Tam WSW, Wong TW. Clustered Randomized Controlled Trial of a Hand Hygiene Intervention Involving Pocket-Sized Containers of Alcohol-Based Hand Rub for the Control of Infections in Long-Term Care Facilities. Infect Control Hosp Epidemiol [Internet]. 2011 [cited 2020 September 29];32:67-76. Available from: http://www.ncbi.nlm.nih.gov/pubmed/21087125.

[20] Behnke M, Gastmeier P, Geffers C, Mönch N, Reichardt C. Establishment of a National Surveillance System for Alcohol-Based Hand Rub Consumption and Change in Consumption over 4 Years. Infect Control Hosp Epidemiol [Internet]. 2012 [cited 2020 September 29]; 33:61820. Available from: http://www.ncbi.nlm.nih.gov/pubmed/22561718.

[21] The World Health Organisation. Protocol for Evaluation of tolerability and acceptability of alcohol-based handrub in use or planned to be introduced: Method 1 [Internet]. 2009 [cited 2020 August 25]. Available from: https://www.who.int/gpsc/5may/Protocol_for_Evaluation_o f_Handrub_Meth1.doc?u a=1Return

[22] Horng, Wen-Bing \& Lee, Cheng-Ping \& Chen, Chun-Wen. (2001). Classification of Age Groups Based on Facial Features. Tamkang Journal of Science and Engineering. 4. 183-192. 


\section{QUESTIONNAIRE - PART 1}

(To complete once per participant, after 1 month)

\begin{tabular}{|l|l|}
\hline Participant no: & \\
\hline Date of questionnaire's return: (day / month / year) & \\
\hline
\end{tabular}

Section 1. EVALUATION OF FACTORS INFLUENCING SKIN TOLERANCE

Age

Sex:

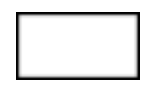

Female

Male

Group:

STUDENTS

FACULTY - NON SCIENCE MAJOR $\square$ OTHERS

FACULTY-NATURAL SCIENCE MAJORTAFF

SKIN TYPE:

LIGHT BROWN

-BLACK

VERY FAIR WITH FRECKLES

BROWN

FAIR \pm FRECKLES

\section{DARK BROWN}

PRESENT SEASON:

COLD

INTERMEDIATE

DRY

HOT

HUMID

Do you have non work-related activity (ies) likely to cause damage to your skin?

Yes $\quad$ No

Do you develop irritative dermatitis?

$\square$ Never $\square$ Sometimes (depending on season/activity) $\square$ Always

Do you develop atopic dermatitis?

$\square$ Yes $\square$ No

Do you develop rhinitis / allergic conjunctivitis?

$\square$ Yes $\quad \square$ No

Are you asthmatic?Do you have a known intolerance to alcohol?

$\square$ Yes $\quad \square$ No $\square$ Yes $\square$ No 
Section 2. EVALUATION OF FREQUENCY OF HAND HYGIENE PRACTICES

1. Do you usually use a hand lotion?

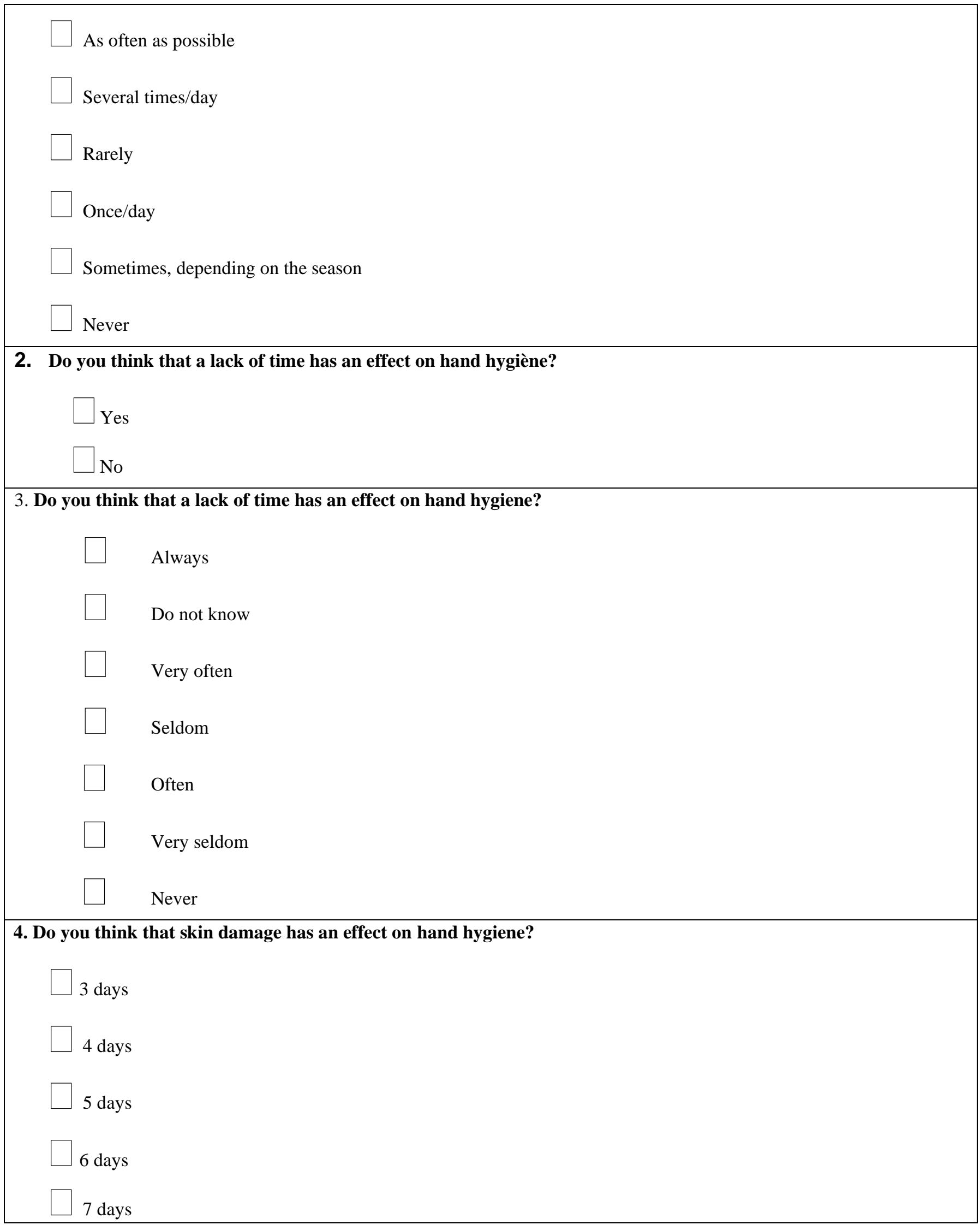


$\square>7$ days

$\square$ Never

5. During how many consecutive days have you used the test product? (days)

Often

Very seldom

Always

Do not know

Never

Very often

Seldom

6. For how long have you been using an alcohol-based hand hygiene product at work?

It's the first time

Since $<1$ year

Since $>1$ year and $<5$ years

Since $>5$ years

7. Do you think you can improve your own hand hygiene compliance?

Yes

No

Perhaps

8. It may be difficult for you to use an alcohol-based hand hygiene product because of:

1. Forgetfulness

$$
\text { Always } \square \text { - - - } \square \text { - - - } \square \text { - - - } \square \text { - - - } \square \text { - - - } \square \text { - - - } \square \text { Never }
$$

2. Lack of time

$$
\text { Always } \square \text { - - - } \square \text { - - - } \square \text { - - - } \square \text { - - - } \square \text { - - - } \square \text { - - - } \square \text { Never }
$$

3. Damaged skin

$$
\text { Always } \square \text { - - - } \square \text { - - - } \square \text { - - - } \square \text { - - - } \square \text { - - - } \square \text { - - - } \square \text { Never }
$$

QUESTIONNAIRE - PART 2(To be completed after the first 3-5 consecutive days of product use) 


\begin{tabular}{|l|l|l|l|}
\hline Participant $\mathrm{n}^{\mathrm{o}}:$ & Product: & $\begin{array}{l}\text { Alcohol based antiseptic } \\
\text { solution }\end{array}$ \\
\hline & & & \\
\hline $\begin{array}{l}\text { Date of questionnaire's return (day / } \\
\text { month / year): }\end{array}$ & & Participant name: & \\
\hline Number of distributed bottles & & $\begin{array}{l}\text { Amount of Product used } \\
(\mathrm{ml}):\end{array}$ & \\
\hline
\end{tabular}

\section{Section 1. EVALUATION OF FREQUENCY OF HAND HYGIENE PRACTICES}

1. Do you usually use a hand lotion?
$\square$ As often as possible $\square$
4 days $\square 5$ days
6 days
7 days $\square>7$ days

2. In what percentage of times where hand hygiene is recommended, do you really clean your hands?
$\square 0 \% \square 10 \%$
$20 \%$
$30 \%$
$40 \%$
$50 \%$
$60 \%$
$70 \%$
$80 \%$
$90 \%$
$100 \%$

3. Has the present study changed your hand hygiene practice?
$\square$ Yes
No

4. During your last 5 opportunities for hand hygiene, how many times did you use hand rubbing to clean your hands?
$\square 0 \square 1 \square 2 \square 3 \square 4 \square 5$

5. On average, how often do you practise hand hygiene during a working hour (during the test period)?
$\square<1 \square$ Between 1 and 5
Between 6 and 10
Between 11 and 15
$\square$ > 15 Section

\section{EVALUATION OF THE TEST PRODUCT}

What is your opinion of the test product for hand hygiene?

1. Colour

\begin{tabular}{|l|l|}
\hline$\square$ Strongly Unpleasant & $\square$ More or less Pleasant \\
\hline$\square$ Unpleasant & $\square$ Pleasant \\
\hline$\square$ More or Less Unpleasant & $\square$ Strongly Pleasant \\
\hline$\square$ Undecided & \\
\hline
\end{tabular}

Smell

\begin{tabular}{|l|l|}
\hline$\square$ Strongly Unpleasant & $\square$ More or less Pleasant \\
\hline$\square$ Unpleasant & $\square$ Pleasant \\
\hline
\end{tabular}




\begin{tabular}{|l|l|}
$\square$ More or Less Unpleasant & $\square$ Strongly Pleasant \\
$\square$ Undecided &
\end{tabular}

\section{Texture}

\begin{tabular}{l|l}
\hline$\square$ Very sticky & $\square$ More or less not sticky \\
\hline$\square$ Sticky & $\square$ Somewhat not sticky \\
\hline$\square$ More or Less sticky & $\square$ Not sticky \\
\hline$\square$ Undecided &
\end{tabular}

\section{Irritation (stinging)}

\begin{tabular}{|l|l|}
\hline$\square$ Very much irritating & $\square$ Undecided \\
\hline$\square$ Much irritating & $\square$ Somewhat irritating \\
\hline$\square$ Irritating & $\square$ Not at all irritating \\
\hline
\end{tabular}

4. Drying effect

\begin{tabular}{l|l|}
\hline$\square$ Very much & $\square$ More or less no \\
\hline$\square$ Much & $\square$ Somewhat \\
\hline$\square$ More or Less & $\square$ Not at all \\
\hline$\square$ Undecided &
\end{tabular}

\section{Ease of use}

\begin{tabular}{|l|l|}
\hline$\square$ Very difficult & $\square$ Easy \\
\hline$\square$ More or less difficult & $\square$ More or less easy \\
\hline$\square$ Difficult & $\square$ Very easy \\
\hline$\square$ Undecided & $\square$ \\
\hline
\end{tabular}

\section{Speed of drying}




\begin{tabular}{|l|l|}
\hline$\square$ More or less slow & $\square$ More or less fast \\
\hline$\square$ Slow & $\square$ Very fast \\
\hline$\square$ Undecided & \\
\hline
\end{tabular}

7. Application

\begin{tabular}{l|l|}
\hline$\square$ Strongly Unpleasant & $\square$ More or less Pleasant \\
\hline$\square$ Unpleasant & $\square$ Pleasant \\
\hline$\square$ More or Less Unpleasant & $\square$ Strongly Pleasant \\
\hline$\square$ Undecided & \\
\hline
\end{tabular}

8. Overall evaluation

\begin{tabular}{|l|l|}
\hline$\square$ Very satisfied & $\square$ Dissatisfied \\
\hline$\square$ More or less satisfied & $\square$ More or less dissatisfied \\
\hline$\square$ More or Less Agree & $\square$ Very dissatisfied \\
\hline$\square$ Satisfied & \\
\hline
\end{tabular}

9. Are there differences between the test product and the commercial product?

\begin{tabular}{|l|l|}
\hline$\square$ Strongly agree & $\square$ More or less disagree \\
\hline$\square$ Agree & $\square$ Disagree \\
\hline$\square$ More or Less Agree & $\square$ Strongly disagree \\
\hline$\square$ Undecided & \\
\hline
\end{tabular}

10. Which product do you prefer?

Usual product

Test product

No preference 
11. Do you think that the test product could improve your hand hygiene compliance?

\begin{tabular}{|l|l|}
\hline$\square$ Strongly agree & $\square$ More or less disagree \\
\hline$\square$ Agree & $\square$ Disagree \\
\hline$\square$ More or Less Agree & $\square$ Strongly disagree \\
\hline$\square$ Undecided & \\
\hline
\end{tabular}

\section{Section 3. EVALUATION OF SKIN CONDITION}

Self-assessment of the skin on your hands (after use of the test product):

1. Appearance(Supple, red, blotchy, rash)

Abnormal $\square \square \square \square \square \square \quad$ Normal

2. Intactness (abrasions, fissures)

Abnormal $\square \square \square \square \square \square \quad$ Normal

3. Moisture content (dryness)

Abnormal $\square \square \square \square \square \square \quad$ Normal

4. . Sensation (itching, burning, soreness)

Abnormal $\square \square \square \square \square \square \quad$ Normal

5. How would you assess the overall integrity of the skin on your hands?

Very altered $\square \square \square \square \square \square$ Perfect

Thank you for your participation!

The Researchers 